\author{
Enrico Forti \\ UCL School of Management \\ University College London \\ 1 Canada Square \\ London E14 5AB, United Kingdom \\ e.forti@ucl.ac.uk \\ Serena Morricone* \\ SDA Bocconi School of Management \\ Via Sarfatti 10 \\ 20136 Milano, Italy \\ serena.morricone@sdabocconi.it \\ Federico Munari \\ Department of Management \\ University of Bologna \\ Via Capo di Lucca, 34 \\ 40126 Bologna, Italy \\ federico.munari@unibo.it
}

*Corresponding author. Authors are listed in alphabetical order. 


\title{
LITIGATION RISKS AND FIRMS INNOVATION DYNAMICS AFTER THE IPO
}

\begin{abstract}
An Initial Public Offering (IPO) is a critical event in a firm's life cycle which can reshape its innovation strategy. Research suggests that after going public firms experience an increase in patent productivity. Our paper explores perceived litigation risks as a determinant of this outcome by examining US semiconductor firms. Results show that perceived patent litigation risks are positively associated with patent productivity after the IPO. Interestingly, we also find that the amount of capital raised during the IPO is positively associated with patent productivity after the IPO, successfully replicating previous findings on this relationship. These results are robust to model specifications where we attempt to account for the dynamics of self-selection of firms into IPO by considering matched control firms with similar pre-IPO characteristics, but that never went public.
\end{abstract}

Keywords: Technology Ventures, Initial Public Offering (IPO), Innovation, Patents, Litigation 


\section{Introduction}

Initial public offerings (IPOs) are a pivotal event in the life of technology ventures providing access to considerable monetary and non-monetary resources to enhance their growth trajectories. Although the effects of resource munificence ${ }^{1}$ on post-IPO venture performance are relatively well understood (Brau and Fawcett, 2006; Pagano et al. 1998; Samila and Sorenson, 2010), a growing stream of studies has shown that IPOs can also reshape firms innovation strategies. Multiple studies report, for example, that firms' overall innovative productivity increases after IPOs, but that these innovations are often less risky and characterized by less exploration (Aggarwal and Hsu, 2014; Chang, Lee, and Wong, 2018; Wies and Moorman, 2015; Wu, 2011).

We contribute to this stream of research by examining whether the increase in patenting reported by previous studies is influenced by firm's expectations regarding competitive interactions that may arise upon successfully completing an IPO — such as risks of patent litigation and other potentially costly legal disputes.

Litigation risks are a potentially important factor because technology ventures often operate in industries characterized by considerable uncertainty, not only in technical and commercial terms, but often also in competitive, legal and regulatory terms. In such contexts, beyond the beneficial effects for the firm that goes public (Samila and Sorenson, 2010, 2017) an IPO sends a powerful signal of legitimation and future growth to relevant external audiences, which also include the managers and investors of potentially competing firms (Lee et al. 2011). In other words, before an IPO, the high degree of novelty of the technologies developed by entrepreneurial firms often leads to information asymmetry between market

\footnotetext{
${ }^{1}$ Resource munificence captures the availability of financial or non-financial resources that may be immediately deployed by the firm (Chang et al., 2018; Dess and Beard, 1984; Nohria and Gulati, 1996).
} 
actors (Reuer et al., 2012) $)^{2}$ Interestingly, this presents both a problem and an opportunity for entrepreneurial firms. On the one hand, asymmetries between market actors impair the ability of startups to mobilize commercialization partners and other audiences that take part in the collective action processes (Lee et al., 2018) surrounding the IPO. On the other hand, the very same asymmetries can serve as an obfuscation device that isolates entrepreneurial firms from a variety of complex competitive interactions, such as patent litigation and other potentially costly legal disputes that can be associated with the discovery and implementation of a new value proposition (Somaya, 2003).

A corollary to this finding, therefore, is that the IPO event increases the likelihood of competitive interactions between IPO firms and other market actors which can range from hostile acquisitions (Reuer et al., 2012) to patent litigation and other potentially costly legal confrontations (Somaya, 2003, 2012). Patent disputes are a particularly pressing issue for new technology ventures and anecdotal evidence on the patent infringement claims received by Google, Facebook, and Twitter just before their IPO dates illustrate how widespread is the phenomenon. These and other technology firms struggle with infringement claims and prefer to settle quickly patent disputes to avoid disrupting financing deals and IPOs (WSJ, 2013). Such risks are particularly pronounced in high-tech sectors, due to the emergence and diffusion of non-practicing entities (often referred to as "Patent trolls"), which specialize in generating licensing revenues through aggressive litigation strategies (Leiponen and Delcamp, 2019). Extant research shows that an IPO affects the innovation strategy of technology ventures as measured by patenting activity (Wu, 2011), yet we do not know whether perceived risks of patent litigation play a role in this process.

\footnotetext{
${ }^{2}$ Research on market formation has identified aspects of uncertainty including lack of knowledge about technologies and product categories (Grodal et al., 2015; Rindova and Petkova, 2007), about dimensions of value within categories (Lee et al. 2018; Rosa et al., 1999), and about industry architectures (Ambos and Birkinshaw, 2010; Dattée et al., 2018; Santos and Eisenhardt, 2009).
} 
In this paper we ask whether technology ventures' perceived patent litigation risks - i.e., expectations of heightened chance of litigation on patent issues upon successfully completing the IPO process - affect their post-IPO innovation strategy. Our key contribution is to exploit information disclosures in the IPO prospectus to offer novel insights on the effect of an important but not fully investigated construct: perceived patent litigation risk. Consistent with other studies, our empirical approach exploits patenting activity to characterize firm innovation strategy (Lahr and Mina, 2016; Wu, 2011). We then use established word content analysis methods to measure to what extent different technology ventures disclose risks of litigation in the IPO prospectus (Hanley and Hoberg, 2010, 2012; Loughran and McDonald, 2014, 2016). We test our theory on a sample of 70 US semiconductor firms that completed an IPO between 1996 and 2007 and attempt to account for self-selection of firms into IPO by considering matched pairs of technology ventures with similar pre-IPO characteristics, but that never went public.

We discuss two main results. First, we show that higher reported risks of patent litigation are positively associated with increased patent productivity after IPO. Second, we replicate previous findings on the positive effect of resource munificence, as measured by IPO proceeds, on post-IPO patent productivity. The greater is the amount of capital that a firm secures with the IPO, the greater will be patent productivity three years after the IPO. This successfully replicates the result of $\mathrm{Wu}$ (2011) in a different empirical setting, highlighting the role of IPOs as pivotal event in reshaping firms' strategic orientations and responding to an increasing demand for replication in the academic community (Bettis, 2012; Bettis et al., 2016; Loken and Gelman, 2017).

What we believe is interesting and novel in our study is the role of patent litigation risk as a potential mechanism to explain increased firm patent productivity after IPOs. This new result extends previous studies on the impacts of IPO on firms' innovative productivity 
by highlighting substantial differences among specific correlates of the innovation strategy of technology-based firms: perceived patent litigation risk and resource munificence. It also contributes to the literature on firms' strategies to address patent litigation risks (Guellec and Van Pottelsberghe, 2007; Hall and Ziedonis, 2001; Bessen and Maurer, 2005), highlighting the IPO as a critical event where to unfold such strategies. Our key result is that firms that are concerned about litigation increase the number of patent applications after the IPO. The interpretation is that technology ventures, at least in our context, seem to be aware that going public enhances a firm's visibility, thus making it an attractive target for infringement claims by competitors and modify their innovation strategy accordingly.

\section{Theory \& Hypotheses}

\subsection{Resource Munificence and Post-IPO Innovative Productivity}

Going public provides significant liquidity that firms can use to finance investments and growth as well as to reconcile current obligations (Deeds et al., 1997; Pagano et al., 1998; Brau and Fawcett 2006; Wu 2011). Beyond the needs of capital, firms going public are able

to increase their legitimacy in the business community, improve access to debt financing, and allow the exit of major shareholders (Engelen et al., 2018). IPOs also function as signals, helping young technology ventures to overcome the liability of newness and attract strategic resources (Wu, 2011). This legitimacy-enhancing dimension of IPOs can be particularly relevant to technology ventures as the increased reputation and media exposure associated with going public can foster the formation of partnerships (Stuart et al., 1999) and the acquisition of non-financial resources that are critical for innovative productivity (Brau and Fawcett, 2006). Research has shown that IPOs are associated with increases in the size of 
technology ventures. Carpenter and Petersen (2002), for instance, observed that U.S. hightech firms experienced a $70 \%$ increase in the number of employees five years after the IPO.

Nevertheless, although new technology ventures that go public benefit from substantial capital injections at the IPO, about half fail within a decade (e.g., Demers and Joos, 2007; Fama and French, 2004). Firms that go public are also exchanging constraints in term of financial and strategic resources with increased organizational formalization, and external market pressure for tangible results (Aggarwal and Hsu, 2014; Pollock and Rindova, 2003; Wies and Moorman, 2015; Wu, 2011). The resource munificence brought by the IPO comes with increased organizational formalization and significant changes in the ownership structure of technology ventures, including managerial ownership dilution and a new class of institutional investors (Wu, 2011).

Intuitively, the resources gained from going public provide a stock of capital that can enhance a firm's ability to fund its R\&D projects after the IPO and boost its innovative productivity (Greve, 2007). However, some scholars point out that the short-term earnings goals of institutional shareholders may discourage firms to use IPO proceeds for radical innovation (Graves, 1988; Arend et al., 2013) while others suggest the opposite (Hansen and Hill, 1991; Hall and Lerner, 2009). On the one hand, organizational transformations tied to the IPO process have been proposed as potential causes for the relatively high number of IPO firms that fail short after the going public (Demers and Joos, 2007), however limited evidence exists on the direction of the effect of external market pressures on innovative activities. On the other hand, both Wu (2011) and Arend and colleagues (2014) maintain that although firms going public can be exposed to investors' short-termism and that capital market participants may have preferences about incremental rather than radical innovation, nevertheless a large number of them generally cheers overall innovative productivity. 
The net effect of resource munificence on a firm's innovative productivity is likely to depend on the relative magnitudes of decreased financial constraints, increased organizational formalization, increased pressures from investors, and perceived importance of patenting as a vehicle to protect a firm's innovation. We argue that gains to innovative productivity linked to IPO-proceeds will dominate potential disruptions caused by new organizational constraints. Accordingly, we hypothesize that the greater are the proceeds that a firm is able to receive from an IPO, the greater will be the likelihood that a firm's overall level of innovative productivity will increase after the IPO.

\section{Hypothesis 1. Firms with greater resource munificence will be characterized by} greater patent productivity after the IPO.

\subsection{Perceived litigation risks and Post-IPO Innovative Productivity}

Different risks factors may hamper the long-run prospects of technology ventures undertaking an IPO. The positive signal emanating from an IPO is particularly relevant for competitors and other incumbents with significant R\&D investments (Arend, Patel, and Park, 2014; Hanley and Hoberg, 2012). One specific source of risk, which has gained increasing importance in high-tech sectors over the last three decades, is related to potential legal disputes on intellectual property rights (Hanley and Hoberg, 2012; Jaffe and Lerner, 2006). Several studies have documented a dramatic increase, starting in the early 1990s, in the number of patent lawsuits filed in the United States and in the related economic costs for companies (Bessen and Meurer, 2008), a phenomenon which has been labeled as "patent litigation explosion" by Bessen and Meurer (2005). This trend has emerged as a consequence of the steep increase in the number of low-quality patent filings and the diffusion of strategic uses of the patent system by companies (Guellec and Van Pottelsberghe, 2008). The 
emergence of fragmented, uncertain and highly litigious patent landscapes has ultimately raised the costs of innovation for firms, in particular in some sectors such as ICT (Bessen and Meurer, 2008). In addition to that, in this landscape, new competitive actors have emerged that specialize in the acquisition and enforcement of patents as a way to generate licensing payments, typically defined as "non-practicing entities" (NPEs)(Leiponen and Delcamp, 2019). Certain NPEs, particularly those that do not directly develop and commercialize inventions, are often referred to as "patent trolls" for their aggressive patent enforcement actions against target companies. The diffusion of such entities in certain sectors (in particular in the software and ICT sector) significantly increases the likelihood of facing legal actions on IPR issues for high-tech companies (Reitzig et al., 2007).

Extant literature has investigated, the determinants and economic consequences of patent disputes (Paik and Zhu, 2016; Somaya, 2012) and strategic disclosure as a hedge against litigation risk (Hanley and Hoberg, 2012), but no specific attention has been devoted on how perceived patent litigation risk may affect the innovation strategies of technology ventures, in particular before and after a substantial inflection point such as an IPO. Going public enhances a firm's visibility and its endowment of financial resources (Pollock and Gulati, 2007), thus making it an attractive target for litigation attacks by competitors. The cost of resolving patent disputes can be substantial and new public firms face dramatically increased hazards of litigation as plaintiffs and even more rapidly increasing hazards as defendants (Bessen and Meurer, 2008). In addition to such direct legal costs, the reputation costs and the opportunity costs of the time that management must allocate to the lawsuits represent an additional potential liability for an IPO firm (Lowry and Shu, 2002). Such direct and indirect costs can have substantial consequences for the short-term and long-term financial performance of IPO firms, by affecting for instance IPO underpricing or stock price volatility (Hanley and Hoberg, 2012). 
Companies can adopt different strategies in order to cope with increasing risks of patent disputes, including abandoning or modifying research projects, exchanging or licensing-in IP, taking legal actions to deal with or avoid problems of access to IP, engaging in negotiations with patent holders to avoid legal disputes (Hall and Ziedonis, 2001). Mueller and colleagues (2012) show, for example, that modifying innovation projects in order to comply with available IP and circumvent potential infringement risks represents the more frequent strategy to cope with problems related to access to intellectual property.

Increasing patenting may provide additional strategic advantages for companies operating in highly fragmented and litigious technology and IP markets (Hall and Ziedonis, 2001). Investing resources to generate a higher number of patented inventions may represent a suitable strategy for IPO firms to avoid or cope with litigation risks. Indeed, several studies have documented an increased diffusion of strategic uses of patents, such as blocking competitors, preventing patent infringement lawsuits by third parties by possessing own patents, or improving the position in cross-licensing or licensing negotiations (Arundel, 2001; Blind et al. 2006; Cohen et al. 2000; Graham et al. 2010). This is particularly true in ICT sectors, including semiconductors, in which firms typically require access to a thicket of external intellectual property to advance technology or to legally manufacture and sell products. In this context, a firm's patent portfolio can be leveraged as a bargaining chip in order to deal with potential patent hold-up problems and force competitors into negotiations (Cohen et al., 2000; Hall and Ziedonis, 2001). In this sense, several studies have documented that patented inventions of firms with larger patent portfolios are less likely to be involved in patent litigation cases (Lanjouw and Shankerman, 2004; Galasso et al., 2013). For such reasons, we advance the following hypothesis:

Hypothesis 2. Firms with higher perceived patent litigation risk will be characterized by greater patent productivity after the IPO. 


\section{Methods}

\subsection{Empirical setting}

The U.S. semiconductor industry represents an ideal context to study the effects of IPOs on innovation for several reasons. First, firms operating in this industry are extremely likely to be affected by patent litigation, as also documented by previous literature (Hall and Ziedonis 2001). Perceived litigation risks are thus particularly relevant issues for new technology ventures that compete in this industry. Second, rapid technological change and high levels of R\&D have constantly characterized the industry and there is a widespread recourse to patenting by semiconductor firms. The number of semiconductor-related patents in the United States has risen sharply since the early 1980, well above the overall increase in patenting (Hall and Ziedonis, 2001). In 2010, seven of the top fifteen US corporate patent recipients were semiconductor companies (US Patent and Trademark Office, 'Patenting by Organizations 2010’, April 2011).

\subsection{Sample \& Data Sources}

We base our analyses on a sample of 70 semiconductor companies that went public in the United States between 1996-2007 and 69 private firms (potential controls). ${ }^{3}$ The list of firms was compiled using the Securities Data Corporation (SDC) database. Starting from an initial sample of 130 IPO firms identified in the SDC database, we retrieved accounting data from the Worldscope database and we obtained companies founding dates from Ritter's data set (Loughran and Ritter, 2004). After removing firms with missing data, the final sample

${ }^{3}$ Our observation period begins in January 1996 because IPO prospectuses are available on the SEC Electronic Data Gathering, Analysis, and Retrieval (EDGAR) service only. 
included 70 IPO firms. To measure perceived risks of patent litigation we retrieved these firms' disclosures from their IPO prospectuses (the primary source of information on newly issued stocks). We assembled patent data using the Delphion database. The sample of IPO firms was subsequently matched with a sample of similar companies that remained private, as described in detail in the next section.

\subsection{Empirical strategy}

A key challenge in assessing the effect of IPOs on firms' innovative productivity is that unobservable factors could simultaneously drive the IPO decision as well as the firms' innovation strategy. In our empirical strategy we attempt to account for self-selection into IPO by using matched pairs of firms with similar characteristics that never did an IPO. More specifically, we considered the IPO event as a "treatment" and collected data on "non-IPO" firms to be regarded as "untreated" controls (Cochran and Rubin, 1973; Bertrand et al., 2004). To identify potential "non-IPO" candidates for the matching procedure we retrieved information from Thomson One VentureXpert on all VC-backed companies operating in the semiconductor industry that were active during our observation period (1996-2007), but that never went public. ${ }^{4}$ The sample for the matching procedure initially included 165 candidate controls (private firms). However, since we are interested in measuring innovative productivity, we retrieved bibliographic data on all patents filed at the USPTO by each firm using the Delphion database. After removing firms that did not file patents during our window of observation (1996-2007) the final sample used for the matching procedure included 70 IPO firms (treated) and 69 private firms (potential controls).

\footnotetext{
${ }^{4}$ Since an IPO represents the most profitable exit route for VC investors (Gompers and Lerner, 1999), it becomes in principle a major strategic objective for VC-backed companies. For such reason, we decided to refer to $\mathrm{VC}$-backed companies in order to construct our control group.
} 
Firms that go public could differ in unobservable ways from firms that do not, such as in the quality of their underlying products and technologies, leading to a higher probability to go public. Matching allows to address differences between firms by selecting a subsample from the data where the treated (IPO firms) and control groups (non-IPO firms) are similar with respect to the matching criteria. This involves a trade-off between how strict is the similarity between matches and the likelihood that a match can be found (Iacus, King, and Porro, 2012). A limitation of our study is the relatively limited source form which we can draw candidate control firms. To provide the strictest possible test, we identify a suitable control for each treated firm by following an exact matching approach with repetition (Lerner, 1999)5. Consistent with previous research on technology ventures, we matched firms by selecting patenting activity, industry segment, founding year, and geographical location as matching criteria (Aggarwal and Hsu, 2014; Fitza, Matusik, and Mosakowski, 2009; Hsu, 2006; Pahnke, Katila, and Eisenhardt, 2015).

Patenting activity is an important matching criterion for our study because we employ patent measures as proxy of innovation activity. We thus select firms that filed patent applications at the USPTO in exactly the same years ( 3 years after and 3 before the IPO year). Finding control firms operating in exactly the same industry segment is also important because specific market opportunities and the availability of complementary assets differ substantially across industry segments (Hsu, 2006; Pahnke et al., 2015) resulting in variation in the number and type of market participants and opportunities for funding (Bertoni, D'Adda, and Grilli, 2019). To provide the strictest possible test, we match each IPO firm with a control firm that has the same four-digit SIC code.

\footnotetext{
${ }^{5} \mathrm{We}$ opt for exact matching on relevant covariates rather than propensity score matching (PSM) because recent research shows that coarsened exact matching (CEM) is likely to produce more balanced matched samples than PSM (Iacus, King, and Porro, 2011, 2012). To provide the strictest test, for each treated firm we find a control firm that matches exactly on the observed covariates.
} 
Similarly, matching firms based on exactly the same founding year is important because the availability of capital, complementary assets, and opportunities is subject to year-to-year variations that may substantially affect the evolution of new technology ventures (Bertoni et al., 2019). We thus select for each IPO firm a control firm that was founded in the exactly same year. Finally, matching firms based on the same geographical location is important because funding opportunities and complementary assets are typically localized (Hsu, 2006; Pahnke et al., 2015). As all of our IPO firms are from the U.S. we match each IPO firm with a corresponding control firm from the U.S., disregarding control firms that do not match this geographical area.

The final sample used for our analysis includes 70 treated (IPO firms). Each of these firms has been matched with one of 28 potential controls (private firms) that have exactly the same observed characteristics discussed above. The observed time period is centered on the IPO year for each IPO-firm and the same year for the firm's matched control. Firms start to be observed 3 years before the IPO and are observed for 3 years after the IPO, which gives a 7year observation window. We followed the approach of the study of Aggarwal and Hsu (2014) for our adoption of a 7-year window across the IPO in the analysis of patent productivity $^{6}$. The matched controls are observed over the same time window of their paired IPO-firms. The matched pairs comparison allows us to compute the difference in innovative productivity between treated and controls before and after the IPO (Cochran and Rubin, 1973; Bertrand et al., 2004).

\subsection{Variables}

\footnotetext{
${ }^{6}$ In their analysis of the innovative behaviour of a sample of US firms going public or being acquired, Aggarwal and Hsu (2014) utilize a 3-year pre-IPO and 3-year post-IPO time window to assess the variation in patent productivity. A similar time window is used by Wies and Moorman (2015) in their comparison of the innovation productivity of a sample of US firms going public with a benchmark of similar private firms. The study by Bernstein (2015) uses a slightly different time window, as it considers patent activity over a period from three years before to five years after the IPO filing, for a sample of US IPOs.
} 


\subsubsection{Dependent variable}

Similar to previous studies (Katila and Ahuja 2002; Hall et al., 2005; Wu, 2011) we characterize firms' innovative productivity by using patent data. Patent applications include a description of a problem and a solution to that problem providing an accurate description of how firms undertake search across different ideas to solve specific problems. Patent data provide a detailed and consistent chronology of research outputs (Katila and Ahuja, 2002). A vast literature in the field of economics and management of innovation has recognized that patent activity reflects the intensity and quality of firms' innovation, despite being characterized by well-known limitations (Lerner and Seru, 2017). Moreover, several studies analyzing the impact of going public on innovation have resorted on patent data in order to measure firms' innovation activities (Bernstein, 2015; Aggarwal and Hsu, 2015; Wu, 2011), thus constituting a benchmark for our study. Finally, our focus on a single sector - the semiconductor industry - characterized by a high importance of patent protection reduces one of the most severe limitations of patent-based measures of innovation, namely the significant heterogeneity in the propensity to patent across sectors.

Based on these considerations, Innovative Productivity is measured for each firm in our sample (treated and controls) by counting the number of patent applications filed during each year of the observation period. As we are interested in the change in the innovative productivity before and after the IPO, the variable used in our models (Innovative Productivity Growth) is computed as the difference between the total stock of patent applications filed three years before the IPO and the total stock of patents filed three years after the IPO. The observation window varies for each firm and is centered on the IPO year for firms going public and the same year for each matched control. We observe all firms 3 years before and after the IPO, which gives a 7-year window of observation. 


$$
\begin{aligned}
& \text { Innovative Productivity Growth }_{i} \\
& \quad=\text { Productivity PostIPO }_{i}-\text { Productivity PreIPO }_{i}
\end{aligned}
$$

After computing the measure above for each treated and each control firm in our sample, we also compute the variable Between Productivity postIPO to measure the difference between each IPO firm and its matched control in the total number of patent applications filed three years after the IPO year. The variable is computed as follows:

(2) Between Productivity postIPO $=$



\subsubsection{Explanatory Variables}

Our key explanatory variable is Perceived patent litigation risk, capturing a firm's perception of the risk of incurring in patent disputes as disclosed in the IPO prospectus. An IPO represents a transformative event for a technology venture in terms of access to financial resources, but also entails an increased commitment to disclose relevant information to potential investors. According to S-K regulation, IPO firms must submit a form (S-1, or IPO prospectus) containing a detailed description of the company's business activities along with the characteristics of the offer and company's financial statements. Both the IPO firm and its underwriter are liable for the information provided as well as for any material omissions in the IPO prospectus (Hanley and Hoberg, 2010). IPO firms are often young with a scant history of verifiable information (Loughran and McDonald, 2013). IPO prospectus provide significant amount of qualitative information on the business strategy employed by technology ventures, including the description of company's proprietary technologies and 
intellectual property assets. Furthermore, in the IPO prospectuses, all firms are required to make explicit references to the possibility of being involved in patent disputes.

The textual analysis of IPO prospectus has been widely employed by accounting and finance researchers to examine mostly the impact of qualitative information on equity valuations (see for a review Li, 2010; Kearney and Liu, 2014; Loughran and McDonald, 2016). As discussed by Loughran and McDonald (2016), although textual analysis is an emerging area in accounting and finance, it is most notably demarcated from quantitative analysis by its imprecision in the measurement. One of the simplest and the most powerful approaches to textual analysis is facilitated by hypotheses that allow the researcher to target a few specific words or phrases.

We thus measure our key explanatory variable of interest - Perceived Patent Litigation Risk — by following the growing body of work that uses content analysis to analyze the information included in the IPO prospectus (e.g., Hanley and Hoberg, 2010, 2012; Loughran and McDonald, 2014). Our goal is to measure to what extent patent litigation is perceived as a threat by examining the disclosure in the IPO prospectuses related to patent litigation related words.

To construct the variable Perceived Patent Litigation Risk we follow Hanley and Hoberg $(2010,2012)$ and evaluate the frequency of word roots related to infringement and litigation as a proxy for a firm's perception of the risk of incurring in patent disputes. We follow this method because, in principle, the higher is the perceived risk of being involved in a patent dispute, the more recurrent should be this aspect in the disclosure that an IPO firm makes in the prospectus and thus the frequency of litigation related words.

Following Hanley and Hoberg $(2010,2012)$, two of the authors red all the IPO prospectuses of the IPO firms in our sample and determined "infringe" and "litiga" as the most relevant set of word roots appearing in IPO prospectus disclosing perceived risks of 
litigation (using the English language word roots identified by Webster.com). For instance,

Marker Communication, one of the IPO firms in our sample, states in the prospectus:

"Many participants in the semiconductor and communications systems industry have a significant number of patents and have frequently demonstrated a readiness to commence litigation based on allegations of patent and other intellectual property infringement. [...] Third parties may assert infringement claims against Maker in the future, which may result in costly litigation. Maker may not prevail in any such litigation or may not be able to license any valid and infringed patents from third parties on commercially reasonable terms, if at all. Litigation, regardless of the outcome, is likely to result in substantial cost and diversion of resources of Maker."

Second, for each IPO firm, we converted the entire text of the IPO prospectus into a character vector that includes all the distinct word in the prospectus while excluding common words, articles, conjunctions, personal pronouns, abbreviations, and compound words because they are not informative regarding content (Hanley and Hoberg, 2012). Finally, we compute a normalized measure of Perceived Patent Litigation Risk for each IPO firm by dividing the total number of times the word roots "infringe" and "litiga" appear in its prospectus by the total number of distinct words that are used in that prospectus (Hanley and Hoberg 2010, 2012). The larger is the measure, the higher is the relative perceived risk of patent litigation that a given IPO firm disclosed in its prospectus.

The identification and use of a specific set of word roots to measure firms' perceived litigation risks builds on established methods in finance and management research which present important advantages. First, once the set is selected, it avoids researcher subjectivity in selecting and coding different sections of the IPO prospectuses. Second, it potentially allows other researchers to replicate the analysis on a different sample of firms. Third, since the method relies on tabulations of the relative frequency of word roots on prospectuses, it can scale to large samples (Loughran and McDonald, 2014, 2016). Finally, compared to other techniques such as sentiment analysis and readability, the analysis of targeted words should limit the innate imprecision of any textual analysis (Loughran and McDonald, 2016). 
Similar to other studies of IPOs, we compute the variable Resource Munificence for each firm as the natural log of the total amount of funding that a company received from the IPO, as reported in the IPO prospectus (Deeds et al., 1997). The amount of capital raised during the IPO is one of the key information that companies must disclose in the IPO prospectus as mandated by the U.S.

\subsubsection{Control Variables}

We control for factors that are likely to affect innovation productivity and patenting. Since the innovation efforts can be negatively affected by external growth, we analyzed the disclosure on the intended use of proceeds in the IPO prospectus. Acquisition is a dummy variable taking the value of one if the company intends to use the IPO proceeds in order to finance future acquisitions including complementary businesses, products and technologies.

Some firm characteristics such as the age and the organizational formalization might as well impact on innovation productivity (Carter et al., 1998; Wu, 2011). We include the natural log of a firm's Age - measured as difference between the IPO year and the company's founding year and a dummy variable, Subsidiary, taking the value of one if the company is a subsidiary. Similarly, a dummy variable Venture-backed identifies companies that received venture capital funding before the IPO.

Innovative productivity is likely to be affected by the firm's level of investments and profitability, we include the natural $\log$ of $R \& D$ investment $(R \& D)$ and we also control for the firm's profitability by including the amount of net income (Profitability). Both variables are calculated based on the last financial statement year prior to the IPO. Finally, we add the full set of year dummies to account for time-specific trends. 


\section{Analysis \& Results}

Our analysis is divided in two parts. We first test our baseline hypothesis (H1) to validate previous findings on the positive impact of IPO on firm innovative productivity. We then test the core hypothesis (H2) on the role of Perceived Patent Litigation Risk in this process.

Tables 1 and 2 report descriptive statistics and correlations.

Table 1 About Here

Table 2 About Here

The average amount of resources collected during the IPO is \$166 millions (mean Resource Munificence 4.09) and 75 percent of companies intends to use the IPO proceeds in order to finance future acquisitions. As the other firms' characteristics, the average firms' age is 13 years and a total of 68 percent of companies have VCs investing in the company before the IPO date. In line with previous studies investigating the IPOs of technology ventures (Morricone et al., 2017), the majority of our sample firms went public having a negative profitability and 20 percent of companies are subsidiaries. Correlation coefficients reported in Table 2 indicate that the innovative productivity of IPO firms is positively related to the financial resources collected during the IPO process (Resource Munificence) and the firm's level of investments in innovation $(R \& D)$.

Figure 1 plots differences in innovative productivity between IPO-firms and controls, before and after the IPO.

Figure 1 About Here

Table 3 About Here

As shown in Figure 1 and Table 3 both IPO-firms and controls grow their stocks of patents overtime, however the innovative productivity (Innovative Productivity Growth) is 
significantly higher for IPO firms (35.47 vs 14.06, t-value 2.56 significant at $1 \%$ level). In particular, before going public IPO firms have on average 8 more patents than their matched controls that never went public (Innovative Productivity pre-IPO), but after going public, IPO firms show on average 29 more patents (Innovative Productivity post-IPO) compared to controls indicating that a relevant gap in productivity between firms emerges after the IPO.

IPO-firms and the matched controls do not statistically differ before the treatment in terms of number of patents (Table 3). Since the use of matching is meant to attenuate the effects of confounding variables that would otherwise concur to cause differences in the indicators of IPO-firms and controls, the observation of similar innovative productivity preIPO suggests that the matching procedure worked well at identifying fairly similar controls.

Table 4 presents our main regression results where we test the effects of IPO proceeds (H1) and perceived risk of litigation (H2) as determinant of Innovative Productivity.

Table 4 About Here

In Hypothesis 1 we argued that greater IPO proceeds could lead to higher innovative productivity. Results support H1 indicating that Resource Munificence has a positive and significant effect on Productivity Growth. The positive and statistically significant coefficient of Perceived Patent Litigation Risk supports Hypothesis 2. The higher are the perceived risks of litigation, the larger is the Productivity Growth. To test the robustness of our results, in Table 5 we present the estimates of the same model using as dependent variables the betweenfirms (treated and controls) difference in innovation productivity after the IPO (Between productivity post-IPO). 
Results confirm that after the IPO the gap in productivity between IPO-firms and controls is associated with the proceeds raised during the IPO and with perceived risks of litigation as the coefficients of Resource Munificence and Perceived Patent Litigation Risk are both positive and statistically significant.

Overall, our results suggest that the IPO process can affect the innovation activities and that IPO and firms' characteristics such as the amount of proceeds and the perceived risks of litigation are associated with changes in innovative productivity.

\section{Discussion \& Conclusions}

We explore the effect of IPOs on firms' innovation strategy by investigating the determinants of post-IPO innovative productivity. Our findings support the view that technology ventures that go public tend to adapt their innovation strategies to the mutated task environment that they must cope with after the IPO. Our comparison of IPO firms and their private peers shows that both types of firms increase their stocks of patents overtime, but that the increase in innovative productivity is higher in IPO firms. The increase in patenting after the IPO could be in part explained in terms of life cycle (i.e., older firms are likely to fall victim to organizational inertia), but in our multivariate analysis we find evidence that the higher growth in innovative productivity is associated with two firm-level factors: the amount of proceeds collected and the perceived risks of patent disputes.

First, our results highlight the importance of IPO as financing deal for technology ventures. Proceeds from going public provide a significant stock of capital and are associated with increased innovative productivity as measured by the growth in patent applications.

Second, while the effect of the IPO on firm's innovative productivity can be partly explained by the injection of fresh financial resources, going public enhances also firm's 
visibility and the risk of being an attractive target for patent disputes - especially in IPintensive industries such as semiconductors. Our results show that IPO firms that fear litigation generate a higher number of patented inventions after going public. An explanation for this result is that patenting becomes more prominent because it is viewed as suitable signal to cope with the increased threat of litigation that IPO firms experience after going public. This is consistent with previous studies, also from the semiconductor industry, showing an increasing recourse to strategic uses of patents, as a way to deter patent disputes from competitors and guarantee the necessary freedom to operate (Guellec and Van Pottelsberghe, 2007; Hall and Ziedonis, 2001). Indeed, especially in ICT sectors, the construction of broad patent portfolios is also related to possibility to sue back in case of patent lawsuits or negotiate better terms in cross-licensing deals (Bessen and Maurer, 2005).

Overall, our study offers novel contributions to two main streams of literature. We contribute to those studies that have started to investigate the effects of critical events such as IPOs (Wu, 2011) and M\&As (Valentini, 2012) on the innovative activities of technology ventures. This emerging stream of research has viewed an IPO as a pivotal event in a technology venture's life cycle, leading to important modifications in patterns of innovative productivity. In the first part of our paper we compare semiconductor firms that went public to private firms that had not yet gone public replicating Wu's (2011) findings about increased post-IPO innovative productivity in a different empirical setting - the semiconductor industry ${ }^{7}$. In the second part of our study we focus on IPO firms only considering firm-level attributes such as the amount of proceeds collected and the perceived risks of patent disputes that yield additional insight into the effect of going public on firms' innovation activities. In this sense, we also contribute to the literature on firms' strategies to cope with patent litigation risks (Hall and Ziedonis, 2001; Leiponen and Belcamp, 2019; Munari and Toschi,

\footnotetext{
${ }^{7}$ We deliberately set out to replicate this previous result because it is central for our theorizing on perceived risks of litigation and to respond to the increasing demand for replication in the academic community (Bettis, 2012; Bettis et al., 2016; Loken and Gelman, 2017)
} 
2014; Reitzig et al., 2007), highlighting the relevance of such risks in the context of the IPO and the responses of newly listed companies in terms of increased patent productivity.

Our results have potentially important managerial implications. As far as the financing of innovation is concerned, our study suggests that firms can leverage financial resources gained from the IPO to increase the overall quantity of innovations. However, it also shows that the decision to go public involves a trade-off between the possibility to gain liquidity and the additional scrutiny and pressures towards profitability that the company receives. This may lead the company to change the nature of the projects in its innovation portfolio, by focusing on more incremental and familiar technologies in order to reap short-term gains. Therefore, this complex trade-off should be carefully considered in order to identify the optimal timing for a firm to go public, especially in technology-intensive sectors.

Another important managerial implication of our study relates to the evidence that we provided on the risks of patent lawsuits for high-tech companies as they approach major funding events such as an IPO, and the related strategies to cope with them. Our study shows that the IPO represents a particularly visible and vulnerable period in a company's development, that can be opportunistically exploited by competitors to strike with patent demands. This is also confirmed by several anecdotal cases, expecially from the ICT sector ${ }^{8}$. Therefore, such risks of litigation should be well considered and assessed by a vast array of stakeholders involved in a company going-public process, including founders and managers, lawyers, investors, underwriters and securities regulators. The company might decide to adopt several strategies to cope with them.

On the one hand, conducting an extensive and thorough IP due diligence in preparation of a major funding event such as an IPO is certainly an important pre-condition to

\footnotetext{
${ }^{8}$ For instance, in 2002 just a few days before its IPO, PayPal received a patent infringement lawsuit that delayed the company's IPO by a week, raising doubts on the media that it would ever go public. In a similar way, in 2012 Facebook was hit by a legal action over patents moved by Yahoo!, just weeks before its planned initial public offering of stock (Feldman and Frondorf, 2015).
} 
limit the subsequent emergence of third-party infringement actions. On the other hand, our study shows that a possible defensive strategy is that of amassing a large portfolio of patents as a way of preemptively strengthening market power and bargaining position. This is line with previous literature showing "patent portfolio races" in some sectors (including semiconductors, the context of our study) aimed at reducing concerns about being held-up by external patent owners and at negotiating access to external technologies through crosslicensing deals (Hall and Ziedonis, 2001; Somaya, 2012). In cases of litigation, the availability of defensive patent portfolios can be exploited with the filing of countersuits and with a higher likelihood of suit settlement (Somaya, 2003). Although such strategy can prove effective from the private point of view of the company, it can generate important social welfare consequences, such as generating a dense web of overlapping intellectual property rights that are difficult to assess and navigate (so-called patent thickets), thus raising uncertainty levels and entry costs for innovators. This presents clear policy implications in terms of optimal design of the patent system, which are well discussed in the literature (Bessen and Meurer, 2008).

\section{Limitations and Future Research}

We wish acknowledge that the paper presents several limitations. Although we shed new light on the relationship between firms' perceived risk of litigation and innovative productivity, we cannot assess whether the increased patent productivity is related to an explicit defensive strategy of "patent fences" (Somaya, 2003, 2012). Second, our measure of the variable Perceived Patent Litigation Risk takes into account the disclosure made by firms in the IPO prospectus. It is important to note that, similar to other natural language processing methods, the dictionary approach we followed may be affected by measurement error 
(Hannigan et al., 2019). A more comprehensive analysis of disclosure behavior could shed more light, for example, on the effective use of trade secrets and a broader conceptualization of the litigation risks perceived by the IPO firm. Similarly, although perceived risks of litigation is likely to be endogenous to the firm, future research could also enlarge the scope of the text analysis to include perceptions about the risk of litigation by external audiences, such as consumers and the media (e.g., de La Bruslerie and Le Maux, 2018). Finally, although we attempt to control for the endogeneity of IPO decision, our matched pairs comparison presents some limitations. As with all approaches based on matching, we can only account for observable covariates. Other unobserved factors that might predict selection into IPO cannot be accounted for in the matching procedure (Heckman and Navarro-Lozano, 2004). In our case, comparability across the samples of IPO-firms and controls was achieved with a strict one-to-one exact matching between treated and control firms on each of the observed covariates. It is important to clarify that we intentionally avoided using variables based on innovative productivity when matching controls (as matching on productivity-related measures would cause selection on those variables that we wish to observe in the analysis). Whereas the exact matching strategy and the resulting sample we used offers multiple advantages, including being geographically confined and strictly identical in terms of industry SIC code, we ended up with a relatively low number of potential controls that could provide a suitable match for the treated firms. We believe it is important to stress that the relatively limited source form which we can draw candidate control firms is a limitation of our study.

Despite these shortcomings, we believe that our paper offers a unique and original contribution to the debate about the role of litigation risks for the innovative productivity of technology firms that do an IPO. Future work could extend our analyses to more industries and to different institutional environments or countries to obtain a larger and more diverse sample and examine potentially relevant contingencies. 


\section{REFERENCES}

Ambos, T. C., \& Birkinshaw, J., (2010). How do new ventures evolve? An inductive study of archetype changes in science-based ventures. Organization Science, 21(6), 1125-1140.

Agarwal, R., \& Helfat, C. E., (2009). Strategic renewal of organizations. Organization Science, 20, 281-293.

Aggarwal, V. A., \& Hsu, D. H., (2014). Entrepreneurial exits and innovation. Management Science, 60(4), 867-887.

Ambos, T. C., \& Birkinshaw, J., (2010). How do new ventures evolve? An inductive study of archetype changes in science-based ventures. Organization Science, 21, 1125-1140.

Arend, R. J., Patel, P. C., \& Park, D. H., (2013). Explaining post-IPO venture performance through a knowledge-based view typology. Strategic Management Journal, 35(3), 376397.

Arundel, A., (2001). The relative effectiveness of patents and secrecy for appropriation. Research policy, 30(4), 611-624.

Bernstein, S., (2015). Does going public affect innovation? Journal of Finance, 70(4) 13651403.

Bertoni, F., D’Adda, D., \& Grilli, L., (2019). Self-selection of entrepreneurial firms in thin venture capital markets: Theory and empirical evidence. Strategic Entrepreneurship Journal, 13(1), 47-74.

Bertrand, M., Duflo, E., \& Mullainathan, S., (2004). How much should we trust differencesin-differences estimates? The Quarterly Journal of Economics, 119, 249-275.

Bessen, J., \& Meurer, M. J., (2005). The patent litigation explosion. Paper presented at American Law \& Economics Association Annual Meetings, 2005.

Bessen, J., \& Meurer, M. J., (2008). Patent failure: How judges, bureaucrats, and lawyers put innovators at risk. Princeton University Press.

Bettis, R. A., (2012). The search for asterisks: Compromised statistical tests and flawed theories. Strategic Management Journal, 33(1), 108-113.

Bettis, R. A., Helfat, C. E., \& Shaver, J. M., (2016). The necessity, logic, and forms of replication. Strategic Management Journal, 37(11), 2193-2203.

Blind, K., Edler, J., Frietsch, R., \& Schmoch, U., (2006). Motives to patent: Empirical evidence from Germany. Research Policy, 35, 655-672.

Brau, J. C., \& Fawcett, S. E., (2006). Initial public offerings: An analysis of theory and practice. Journal of Finance, 61, 399-436. 
Brau, J. C., Francis, B., \& Kohers, N., (2003). The choice of IPO versus takeover: Empirical evidence. Journal of Business, 76, 583-612.

Carpenter, R. E., \& Petersen, B. C., (2002). Is the growth of small firms constrained by internal finance?. Review of Economics and Statistics, 84, 298-309.

Carter, R. B., Dark, F. H., \& Singh, A. K., (1998). Underwriter reputation, initial returns, and the long-run performance of IPO stocks. Journal of Finance, 53, 285-311.

Chang, H. Y., Lee, C. Y., \& Wong, Y. J., (2018). The impact of earnings pressure on exploratory innovation. $R \& D$ Management.49(4), 470-483.

Cochran, W. G., \& Rubin, D. B., (1973). Controlling bias in observational studies: A review. Sankhyā: The Indian Journal of Statistics Series A, 417-446.

Cohen, W. M., Nelson, R. R., \& Walsh, J. P., (2000). Protecting their intellectual assets: Appropriability conditions and why US manufacturing firms patent (or not). NBER Working Paper no. 7552, 2000.

de La Bruslerie, H., \& Le Maux, J., (2018). Litigation risk: Measurement and impact on M\&A transaction terms. Journal of Business Finance \& Accounting, 45(7-8), 952-996.

Dattée, B., Alexy, O., \& Autio, E., (2018). Maneuvering in poor visibility: How firms play the ecosystem game when uncertainty is high. Academy of Management Journal, 61(2), 466-498.

Deeds, D. L., Decarolis, D., \& Coombs, J. E., (1997). The impact of firm-specific capabilities on the amount of capital raised in an initial public offering: Evidence from the biotechnology industry. Journal of Business Venturing, 12, 31-46.

Demers, E., \& Joos, P., (2007). IPO failure risk. Journal of Accounting Research, 45, 333371.

Dess, G. G., \& Beard, D. W., (1984). Dimensions of organizational task environments. Administrative Science Quarterly, 52-73.

Engelen, P. J., Heugens, P., van Essen, M., Turturea, R., \& Bailey, N., (2018). The impact of stakeholders' temporal orientaton on short-and long-term IPO outcomes: A meta-analysis. Long Range Planning, In Press.

Fama, E. F., \& French, K. R., (2004). New lists: Fundamentals and survival rates. Journal of Financial Economics, 73, 229-269.

Feldman, R., \& Frondorf, E., (2015). Patent demands and initial public offerings. Stan. Tech. L. Rev., 19, 52 . 
Fitza, M., Matusik, S. F., \& Mosakowski, E., (2009). Do VCs matter? The importance of owners on performance variance in start-up firms. Strategic Management Journal, 30(4), 387-404.

Galasso, A., Schankerman, M., \& Serrano, C. J., (2013). Trading and enforcing patent rights. The RAND Journal of Economics, 44, 275-312.

Gompers, P., \& Lerner, J., (1999). An analysis of compensation in the US venture capital partnership. Journal of Financial Economics, 51, 3-44.

Graham, S. J., Merges, R. P., Samuelson, P., \& Sichelman, T., (2009). High technology entrepreneurs and the patent system: Results of the 2008 Berkeley patent survey. Berkeley Technology Law Review, 24, 1258-1328.

Graves, S. B., (1988). Institutional ownership and corporate R\&D in the computer industry. Academy of Management Journal, 31, 417-428.

Greve, H. R., (2007). Exploration and exploitation in product innovation. Industrial and Corporate Change, 16, 945-975.

Grodal, S., Gotsopoulos, A., \& Suarez, F. F., (2015). The coevolution of technologies and categories during industry emergence. Academy of Management Review, 40(3), 423-445.

Guellec, D., \& Van Pottelsberghe de la Potterie, B., (2007). The economics of the European patent system: IP policy for innovation and competition. Oxford: Oxford University Press.

Hall, B. H., \& Lerner, J., (2009). The financing of R\&D and innovation. NBER Working Paper no. w15325.

Hall, B. H., \& Ziedonis, R., (2001). The patent paradox revisited: An empirical study of patenting in the U.S. semiconductor industry, 1979-1995. The RAND Journal of Economics, 32, 101-128.

Hall, B. H., \& Ziedonis, R., (2007). An empirical analysis of patent litigation in the semiconductor industry. University of California at Berkeley working paper, 217-242.

Hannigan, T. R., Haans, R. F., Vakili, K., Tchalian, H., Glaser, V. L., Wang, M. S., Kaplan, S. \& Jennings, P. D., (2019). Topic modeling in management research: Rendering new theory from textual data. Academy of Management Annals 13(2): 586-632.

Hanley, K. W., \& Hoberg, G., (2010). The information content of IPO prospectuses. The Review of Financial Studies, 23(7), 2821-2864.

Hanley, K. W., \& Hoberg, G., (2012). Litigation risk, strategic disclosure and the underpricing of initial public offerings. Journal of Financial Economics, 103(2), 235-254.

Hansen, G. S., \& Hill, C.W., (1991). Are institutional investors myopic? A time-series study of four technology-driven industries. Strategic Management Journal, 12, 1-16. 
Heckman, J., \& Navarro-Lozano, S., (2004). Using matching, instrumental variables, and control functions to estimate economic choice models. Review of Economics and Statistics, $86,30-57$.

Hsu, D. H., (2006). Venture capitalists and cooperative start-up commercialization strategy. Management Science, 52(2), 204-219.

Iacus, S. M., King, G., \& Porro, G., (2011). Multivariate matching methods that are monotonic imbalance bounding. Journal of the American Statistical Association, 106(493), $345-361$.

Iacus, S. M., King, G., \& Porro, G., (2012). Causal inference without balance checking: Coarsened exact matching. Political analysis, 20(1), 1-24.

Jaffe, A., \& Lerner, J., (2005). Innovation and its discontents: How our broken patent system is endangering innovation and progress, and what to do about it. Princeton: Princeton University Press.

Katila, R., \& Ahuja, G., (2002). Something old, something new: A longitudinal study of search behavior and new product introduction. Academy of Management Journal, 45: $1183-1194$.

Kearney, C., \& Liu, S., (2014). Textual sentiment in finance: A survey of methods and models. International Review of Financial Analysis, 33: 171-185.

Lahr, H., \& Mina, A., (2016). Venture capital investments and the technological performance of portfolio firms. Research Policy, 45(1), 303-318.

Langlois, R. N., \& Cosgel, M. M., (1993). Frank knight on risk, uncertainty, and the firm: a new interpretation. Economic Inquiry, 31(3), 456-465.

Lanjouw, J. O., \& Schankerman, M., (2004). Patent quality and research productivity: Measuring innovation with multiple indicators. The Economic Journal, 114, 441-465.

Lee, B. H., Struben, J., \& Bingham, C. B., (2018). Collective action and market formation: An integrative framework. Strategic Management Journal, 39(1), 242-266.

Lee, S. H., Bach, S. B., \& Baik, Y. S., (2011). The impact of IPOs on the values of directly competing incumbents. Strategic Entrepreneurship Journal, 5(2), 158-177.

Leiponen, A., Delcamp, H., (2019). The anatomy of a troll? Patent licensing business models in the light of patent reassignment data. Research Policy, 48 (1), 298-311.

Lerner, J., (1999). The government as venture capitalist: The long-run impact of the SBIR program. The Journal of Business, 72(3), 285-318.

Lerner, J., Seru, A., (2017). The use and misuse of patent data: Issues for corporate finance and beyond. NBER Working Paper 24053, National Bureau of Economic Research. 
Li, F., (2010). Survey of the literature. Journal of Accounting Literature, 29, 143-165.

Loken, E., \& Gelman, A., (2017). Measurement error and the replication crisis. Science, 355(6325), 584-585.

Loughran, T., \& Ritter, J., (2004). Why has IPO underpricing changed over time?. Financial Management, 33, 5-37.

Loughran, T., \& McDonald, B., (2013). IPO first-day returns, offer price revisions, volatility, and form S-1 language. Journal of Financial Economics, 109, 307-326.

Loughran, T., \& McDonald, B., (2014). Measuring readability in financial disclosures. The Journal of Finance, 69(4), 1643-671.

Loughran, T., \& McDonald, B., (2016). Textual analysis in accounting and finance: A survey. Journal of Accounting Research, 54(4), 1187-1230.

Lowry, M., \& Shu, S., (2002). Litigation risk and IPO underpricing. Journal of Financial Economics, 65, 309-336.

Morricone, S., Munari, F., Oriani, R., \& De Rassenfosse, G., (2017). Commercialization strategy and IPO underpricing. Research Policy, 46(6), 1133-1141.

Mueller, E., Cockburn, I. M., \& MacGarvie, M., (2012). Access to intellectual property for innovation: Evidence on problems and coping strategies from German firms. Research Policy, 42, 529-541.

Munari, F., \& Toschi, L., (2014). Running ahead in the nanotechnology gold rush. Strategic patenting in emerging technologies. Technological Forecasting and Social Change, 83(1), 194-207.

Nohria, N., \& Gulati, R., (1996). Is slack good or bad for innovation?. Academy of management Journal, 39(5), 1245-1264.

Pagano, M., Panetta, F., \& Zingales, L., (1998). Why do companies go public. Journal of Finance, 53, 27-63.

Pahnke, E. C., Katila, R., \& Eisenhardt, K. M., (2015). Who takes you to the dance? How partners' institutional logics influence innovation in young firms. Administrative Science Quarterly, 60(4), 596-633.

Paik, Y., \& Zhu, F., (2016). The impact of patent wars on firm strategy: Evidence from the global smartphone industry. Organization Science, 27(6), 1397-1416.

Pollock, T. G., \& Rindova, V. P., (2003). Media legitimation effects in the market for initial public offerings. Academy of Management Journal, 46, 631-642. 
Pollock, T. G., \& Gulati, R., (2007). Standing out from the crowd: The visibility-enhancing effects of IPO-related signals on alliance formation by entrepreneurial firms. Strategic Organization, 5, 339-372.

Reuer, J. J., Tong, T. W., \& Wu, C. W., (2012). A signaling theory of acquisition premiums: Evidence from IPO targets. Academy of Management Journal, 55(3), 667-683.

Reitzig, M., Henkel, J., Heath, C., (2007). On sharks, trolls, and their patent prey-Unrealistic damage awards and firms' strategies of "being infringed". Research Policy, 36(1), 134 154.

Rindova, V. P., \& Petkova, A. P., (2007). When is a new thing a good thing? Technological change, product form design, and perceptions of value for product innovations. Organization Science, 18(2), 217-232.

Rosa, J. A., Porac, J. F., Runser-Spanjol, J., \& Saxon, M. S., (1999). Sociocognitive dynamics in a product market. Journal of Marketing, 63, 64-77.

Samila, S., \& Sorenson, O., (2010). Venture capital as a catalyst to commercialization. Research Policy, 39(10), 1348-1360.

Samila, S., \& Sorenson, O., (2017). Community and capital in entrepreneurship and economic growth. American Sociological Review, 82(4), 770-795.

Santos, F. M., \& Eisenhardt, K. M., (2009). Constructing markets and shaping boundaries: Entrepreneurial power in nascent fields. Academy of Management Journal, 52(4), 643671.

Somaya, D., (2003). Strategic determinants of decision not to settle patent litigation. Strategic Management Journal, 24, 17-38.

Somaya, D., (2012). Patent strategy and management: An integrative review and research agenda. Journal of Management, 38,1084-1114.

Stuart, T. E., Hoang, H., \& Hybels, R. C., (1999). Interorganizational endorsements and the performance of entrepreneurial ventures. Administrative Science Quarterly, 44, 315-349.

Valentini, G., (2012). Measuring the effect of M\&A on patenting quantity and quality. Strategic Management Journal, 33, 336-346.

Wies, S., \& Moorman, C., (2015). Going public: how stock market listing changes firm innovation behavior. Journal of Marketing Research, 52(5), 694-709.

Wu, G. A., (2011). The effect of going public on innovative productivity and exploratory search. Organization Science, 23, 928-950. 


\section{TABLES \& FIGURES}

Figure 1 - Innovative Productivity: IPO Firms vs. Control Firms

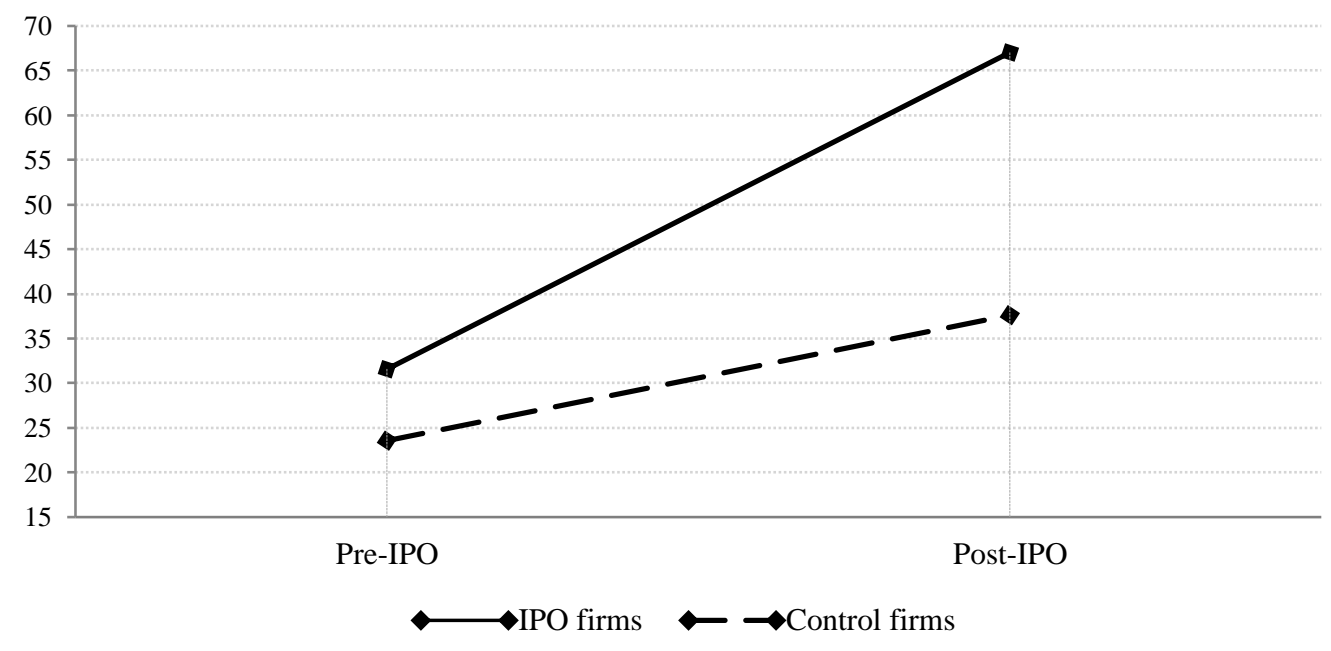


Table 1 - Descriptive Statistics

IPO Firms: Innovative Productivity pre-IPO IPO Firms: Innovative Productivity post-IPO IPO Firms: Innovative Productivity Growth Control: Innovative Productivity pre-IPO Control: Innovative Productivity post-IPO Control: Innovative Productivity Growth Between productivity pre-IPO Between productivity post-IPO

Resource Munificence

Perceived Patent Litigation Risk

Acquisition

Subsidiary

Profitability

R\&D

Age

Venture-backed

\begin{tabular}{cccccc}
$\mathbf{N}$ & Mean & Median & Min & Max & St. Dev. \\
\hline 70 & 31.56 & 13.50 & 0.00 & 283.00 & 51.05 \\
70 & 67.03 & 29.50 & 1.00 & 359.00 & 83.61 \\
70 & 35.47 & 15.50 & -64.00 & 221.00 & 60.65 \\
70 & 23.56 & 13.00 & 1.00 & 360.00 & 47.18 \\
70 & 37.61 & 18.00 & 1.00 & 357.00 & 57.89 \\
70 & 14.06 & 7.00 & -36.00 & 167.00 & 35.13 \\
70 & 8.00 & 0.00 & -350.00 & 267.00 & 67.30 \\
70 & 29.41 & 5.50 & -260.00 & 308.00 & 96.46 \\
70 & 4.09 & 3.80 & 0.99 & 8.01 & 1.26 \\
70 & 0.05 & 0.04 & 0.01 & 0.21 & 0.03 \\
70 & 0.76 & 1.00 & 0.00 & 1.00 & 0.43 \\
70 & 0.20 & 0.00 & 0.00 & 1.00 & 0.40 \\
70 & -6.29 & -0.90 & -256.00 & 106.00 & 39.90 \\
70 & 2.15 & 1.84 & 0.00 & 9.32 & 1.61 \\
70 & 2.25 & 2.20 & 1.10 & 3.93 & 0.77 \\
70 & 0.67 & 1.00 & 0.00 & 1.00 & 0.47 \\
\hline
\end{tabular}


Table 2 - Correlation Matrix

\begin{tabular}{|c|c|c|c|c|c|c|c|c|c|c|c|c|c|}
\hline & & 1 & 2 & 3 & 4 & 5 & 6 & 7 & 8 & 9 & 10 & 11 & 12 \\
\hline 1 & Productivity Growth & 1.00 & & & & & & & & & & & \\
\hline 2 & Productivity post-IPO & 0.80 & 1.00 & & & & & & & & & & \\
\hline 4 & Between Productivity post-IPO & 0.58 & 0.80 & 0.63 & 1.00 & & & & & & & & \\
\hline 5 & Between Productivity pre-IPO & -0.01 & 0.43 & 0.71 & 0.73 & 1.00 & & & & & & & \\
\hline 7 & Perceived Patent Litigation Risk & 0.14 & 0.14 & 0.06 & 0.13 & 0.01 & 0.04 & 1.00 & & & & & \\
\hline 8 & Acquisition & -0.30 & -0.28 & -0.10 & -0.18 & -0.08 & -0.23 & 0.17 & 1.00 & & & & \\
\hline 9 & Subsidiary & -0.23 & -0.20 & -0.06 & -0.25 & 0.01 & 0.00 & 0.01 & 0.03 & 1.00 & & & \\
\hline 10 & Profitability & -0.02 & -0.03 & -0.02 & -0.10 & -0.09 & -0.19 & 0.00 & 0.06 & 0.07 & 1.00 & & \\
\hline 11 & $R \& D$ & 0.32 & 0.34 & 0.18 & 0.27 & 0.10 & 0.29 & 0.01 & -0.43 & 0.05 & -0.26 & 1.00 & \\
\hline
\end{tabular}


Table 3 - Mean Difference of Innovative Productivity

\begin{tabular}{lcccc}
\hline & $\begin{array}{c}\text { Innovative } \\
\text { Productivity } \\
\text { pre-IPO }\end{array}$ & $\begin{array}{c}\text { Innovative } \\
\text { Productivity } \\
\text { post-IPO }\end{array}$ & t-value & $p$-value \\
\cline { 2 - 5 } $\begin{array}{l}\text { Treatment } \\
\text { Control }\end{array}$ & 31.56 & 67.03 & -3.03 & 0.003 \\
& 23.56 & 37.61 & -1.58 & 0.117 \\
& Treatment & Control & t-value & $p$-value \\
\cline { 2 - 5 } $\begin{array}{l}\text { Innovative } \\
\text { Productivity } \\
\text { Pre-IPO }\end{array}$ & 31.56 & 23.56 & 0.96 & 0.337 \\
$\begin{array}{l}\text { Innovative } \\
\text { Productivity } \\
\text { Post-IPO }\end{array}$ & & & & \\
Productivity Growth & 67.03 & 37.61 & 2.42 & 0.017 \\
& & & & \\
\hline
\end{tabular}




\begin{tabular}{lcc}
\hline & \multicolumn{2}{c}{ Innovative Productivity Growth } \\
\cline { 2 - 3 } Resource Munificence & $20.40^{* * *}$ & $(5.51)$ \\
Perceived Patent Litigation Risk & $413.3 * *$ & $(176.30)$ \\
Acquisition & $-22.56^{*}$ & $(12.49)$ \\
Subsidiary & $-57.49 * * *$ & $(16.30)$ \\
Profitability & $0.240^{*}$ & $(0.14)$ \\
R\&D & $9.680^{* * *}$ & $(3.49)$ \\
Age & -1.915 & $(8.26)$ \\
Venture-backed & 20.43 & $(28.26)$ \\
Intercept & $-67.13 * *$ & \\
Year FE & YES & \\
\hline R-squared & & 0.536 \\
Obs & & 70 \\
\hline
\end{tabular}

Robust standard errors in parentheses.

$* * *$ significant at the $1 \%$ level; ** significant at the $5 \%$ level; * significant at the $10 \%$ level in a two-tailed test 
Table 5 - Regression Results: Determinants of Innovative Productivity Growth between Treatment and Controls Firms

\begin{tabular}{lcc}
\hline & \multicolumn{2}{c}{ Between Productivity post-IPO } \\
\cline { 2 - 3 } Resource Munificence & $22.93 * * *$ & $(6.64)$ \\
Perceived Patent Litigation Risk & $444.8^{* * *}$ & $(204.30)$ \\
Acquisition & 1.01 & $(17.15)$ \\
Subsidiary & $-77.27 * * *$ & $(20.77)$ \\
Profitability & 0.179 & $(0.16)$ \\
R\&D & 8.197 & $(4.98)$ \\
Age & 13.41 & $(15.81)$ \\
Venture-backed & 10.46 & $(36.36)$ \\
Between productivity pre-IPO & $0.988^{* * *}$ & \\
Intercept & $-140.1 * * *$ & \\
Year FE & YES & \\
\hline R-squared & & 0.766 \\
Obs & & 70 \\
\hline
\end{tabular}

Robust standard errors in parentheses.

$* * *$ significant at the $1 \%$ level; ** significant at the $5 \%$ level; * significant at the $10 \%$ level in a two-tailed test 